\title{
PENGARUH PENYISIHAN PENCADANGAN ASET, KUALITAS KREDIT, DEWAN KOMISARIS, KOMITE AUDIT, UKURAN DAN KUALITAS AUDITOR TERHADAP MANAJEMEN LABA
}

\author{
FABIO DANIEL HUTAPEA ${ }^{a}$ \\ Ardianto ${ }^{b}$ \\ ${ }^{a}$ Sekolah Pascasarjana Universitas Airlangga ${ }^{\mathrm{b}}$ Fakultas Ekonomi dan Bisnis Universitas Airlangga \\ Email: danielhutapea@yandex.com ${ }^{\text {a }}$; andryirwanto149@gmail.com ${ }^{b}$
}

\section{ARTICLE HISTORY}

Received:

29 Januari 2020

Revised

25 Februari 2020

Accepted:

9 March 2020

Online available:

9 Mei 2020

Keywords:

earnings

management,

loan loss provision,

non performing loans,

boards,

audit commitee,

bank size,

auditor's quality.

\begin{abstract}
Introduction: This research is aimed to prove whether the banking management did the earnings manipulation by loan loss provision, determination of non performing loan and whether the characteristics of supervisory organs in Good Corporate Governance would influence the earnings management practice.

Methods: The data analysis method used in this study is moderated regression analysis. This research was conducted in Indonesia's banking sector from 2011 to 2013.

Results: This research proves that loan loss provision, non performing loan, size of commisioner board, audit commitee meeting frequency have no affect to the earnings management. While bank size affect the earnings management significantly. The quality of auditor has no affect to the relation between loan loss provision, non performing loan to the bank's earnings management.

Conclusion and suggestion: Disclosure policies with respect to the criteria for granting management bonuses and the nature of transactions, requirements and restrictions on creditors regarding loans received by banks will complement research based on positive accounting theory in banking.
\end{abstract}




\section{INTRODUCTION}

State the objectives of the work and provide an adequate background, avoiding a detailed literature survey or a summary of the results. Explain how you addressed the problem and clearly state the aims of your study. As you compose the introduction, think of readers who are not experts in this field. Please describe in narrative format and not using sub-chapter. (Calibri, 12, 1.15 Spacing, Justify)

Laporan keuangan berfungsi sebagai media informasi yang menghubungkan pihak pemilik dengan pihak manajemen. Kinerja manajemen dapat dievaluasi melalui informasi keuangan yang dilaporkan, salah satu indikatornya adalah perolehan laba. Laporan posisi keuangan, laporan aktivitas dan laporan arus kas merupakan beberapa contoh laporan yang seringkali dimanfaatkan sebagai dasar pengambilan keputusan investasi. Agar kinerja perusahaan terlihat baik, maka manajemen berupaya mengatur nilai laba yang disajikan. Pengaturan nilai laba melalui pemilihan kebijakan akuntansi tertentu untuk memaksimalkan utilitas dan atau nilai perusahaan disebut dengan manajemen laba (Scott, 2012).

Manajemen laba terjadi ketika manajer menggunakan pertimbangan dalam melaporkan keuangan dan dalam menyusun transaksi untuk mengubah laporan keuangan sehingga memberi informasi yang menyesatkan pemilik maupun stakeholder tentang dasar ekonomik perusahaan (Healy \& Wahlen, 1999). Bentuk manajemen laba dapat berupa: pengaturan pengakuan transaksi akrual, pemilihan metode penilaian yang berbeda, rekayasa keputusan operasional (menggeser periode biaya atau pendapatan) dan lain-lain. Adanya manajemen laba mengakibatkan terjadinya opaque earning quality, yang berarti informasi laba menjadi tidak transparan dan menyebabkan informasi keuangan menjadi tidak dapat diandalkan.

Manajemen laba terbagi menjadi dua kategori. Pertama, manajemen laba akrualyaitu ketika manajer melakukan manipulasi melalui pengakuan akrual dan tidak memiliki pengaruh terhadap arus kas, misalnya mempercepat dan atau menunda pengakuan pendapatan dan atau beban.Salah satu contoh dalam sektor perbankan adalah penyisihan pencadanganaset produktif yang penentuan dasarnya diserahkan kepada pihak manajemen bank itu sendiri. Hal tersebut lebih mudah dilakukan karena manajemen laba dilakukan melalui penjurnalan. Kedua, manajemen laba riil yaitu ketika manipulasi yang dilakukan melibatkan transaksi yang memiliki pengaruh terhadap arus kas. Hal ini tidak mudah dilakukan mengingat dampak langsungnya pada proses bisnis dan kekayaan pemegang saham (Subramanyam \& Wild, 2009). Menurut Roychowdhury (2006), manajemen laba riil didasari motivasi manajer untuk meyakinkan stakeholder dan pemilikbahwa seolah-olah tujuan tertentu suatu pelaporan keuangan telah berhasil dicapai. Manajemen laba riil umumnya dilakukan dengan cara: manipulasi penjualan, mengurangi beban diskresioner dan meningkatkan produksi secara berlebihan. 
Penelitian oleh Cohen, Dey and Lys (2008) menyimpulkan dua hal: adanya peningkatan praktek manajemen laba yang dilakukan oleh manajer guna menghindari laba negatif dan pasca diberlakukannya Sarbanex Oaxley Act (SOX) terjadi perubahan pilihan dari manajemen laba akrual ke manajemen laba riil, hal ini disebabkan Karena deteksi manajemen laba lebih sulit daripada manajemen laba akrual.

Perbankan sejak lama telah menjadi salah satu pilar kemakmuran ekonomi diseluruh dunia. Sektor tersebut merupakan salah satu pilar perekonomian dalam sistem keuanganyang memiliki peran penting dalam kesuksesan maupun kegagalan perekonomian (Ugbede, Lizam \& Kaseri, 2013). MenurutKamau (2011), praktek perbankan yang sehat dapat mendorong pertumbuhan ekonomi melalui alokasi sumber daya yang efisien ke unit-unit produktif.

Di Indonesia industri perbankan termasuk dalam highly regulated industry dimana Pemerintah melalui Bank Indonesia mengawasi dan menentukan kebijakan atau peraturan terhadap industri terkait. Tidak hanya Bank Indonesia namun lembaga lainnya seperti Direktorat Jendral Pajak, Kementrian Hukum dan Hak Asasi Manusia, Badan Pengawas Pasar Modal dan Lembaga Keuangan (sekarang menjadi Otoritas Jasa Keuangan), Lembaga Penjamin Simpanan bertugas mengawasi jalannya praktek perbankan di Indonesia. Hal ini disebabkan karena sektor tersebut memilikikontribusi yang besar bagi perekonomian dan kegagalan pengelolaan perbankan dapat mengakibatkan dampak yang signifikan bagi perekonomian negara. Bank menghimpun dana dari masyarakat dalam bentuk simpanan dan menyalurkannya kepada masyarakat dalam bentuk kredit dan atau bentuk-bentuk lainnya dalam rangka meningkatkan taraf hidup rakyat banyak. Dengan kata lain, bank dapat didefinisikan sebagai lembaga intermediasi keuangan. Bank harus menjadi pihak yang dapat dipercaya dan transparan agar terbentuk praktek perbankan yang kuat, sehat dan stabil. Kinerja suatu bank tidak terlepas dari peran manajemen sebagai pengelola yang dipimpin oleh seorang manager.

Motivasi penelitian ini yang pertama adalah menggunakan PPA kredit yang diberikan dan kredit bermasalah dalam pengaruhnya terhadap praktek manajemen laba. PPA kredit yang diberikan dapat dimanfaatkan manajer sebagai alat dalam praktek manipulasi laba industri perbankan. Tingkat kredit yang bermasalah merupakan indikator kinerja perbankan dalam mengelola kredit. Praktek manajemen laba dapat dimulai dari penentuan sasaran tingkat kredit bermasalah yang diinginkan oleh manajer. PPA kredit yang diberikan telah digunakan dalam penelitian oleh Tsitinidis and Duru (2013) yang mengukur manajemen laba menggunakan model akrual spesifik - Residual PPA kredit yang diberikan dan Abaoub, Homrani and Ben Gamra (2013) yang mengukur manajemen laba menggunakan akrual aggregat - Modified Jones. Sedangkan penggunaan kredit bermasalah dalam hubungannya dengan manajemen laba telah digunakan dalam 
penelitian oleh Chang, Shen and Fang (2008), Dong, Liu and Hu (2012), Isa et al. (2013), lannotta and Kwan (2013) yang menggunakan model akrual spesifik - Residual PPA kredit yang diberikan. Di Indonesia belum banyak penelitian terkait penggunaan PPA kredit yang digunakan dalam kaitannya dengan praktek manajemen laba. Berbeda dengan penelitian-penelitian terdahulu, penelitian ini menggunakan PPA kredit yang diberikan, tingkat kredit bermasalah, ukuran dewan komisaris, rapat komite audit, ukuran bank dan kualitas auditor dalam pengaruhnya terhadap manajemen laba yang diukur dengan model Adjusted Jones (Yasuda, Okuda \& Konishi, 2004). Model tersebut sesuai untuk mendeteksi praktek manajemen laba perbankan karena menyertakan penyisihan 7 pencadangan aset kredit yang diberikan dan beban penghapusan aset kredit yang diberikan dalam perhitungan beban non kas atau akrual (Yasuda et al., 2004).

Motivasi penelitian kedua berkaitan dengan peran ukuran dewan komisaris, rapat komite audit dan ukuran bank dalam interaksinya terhadap praktek manajemen laba. Kedua organ GCG tersebut diharapkan dapat menekan terjadinya praktek manajemen laba dan dapat mendukung terciptanya transparansi pengungkapan dan praktek akuntansi yang berkualitas tinggi (Ugbede et al., 2013). Penelitian dengan menggunakan karakteristik organ GCG, dewan komisaris dan komite audit telah dilakukan oleh Siswantaya (2007) yang meneliti pengaruh kehadiran dewan komisaris independen dan keberadaan komite audit. Kemudian oleh Pamudji and Trihartati (2010) yang meneliti pengaruh komite audit independen, keahlian anggota, frekuensi rapat, komitmen waktu komite audit. Selanjutnya oleh Guna and Herawaty (2010) yang meneliti pengaruh kehadiran pihak independen dewan dan komite audit. Hari (2012) meneliti pengaruh ukuran dewan komisaris serta Baccouche, Hadriche and Omri (2013) yang melakukan penelitian serupa dengan Ugbede et al. (2013) yang meneliti pengaruh frekuensi rapat, kehadiran pihak independen, status dewan komisaris dengan frekuensi rapat,kehadiran pihak independen, duality komite audit terhadap praktek manajemen laba. Peneliti memilih dewan komisaris dan komite audit karena kedua organ tersebut merupakan berfungsi mengawasi,tidak turut serta dalam pengelolaan manajemen dan memiliki komposisi anggota independen yang memadai. Variabel ukuran dewan komisaris dipilih karena jumlah anggota dewan komisaris menentukan kualitas koordinasi guna mendukung suatu pengawasan yang efektif (Ugbede et al., 2013), dimana semakin banyak jumlah anggota akan 8 mempersulit melakukan koordinasi, komunikasi maupun penyelengaraan pertemuan atau rapat guna membahas isu-isu pengelolaan manajemen. Kemudian peneliti juga menggunakan variabelfrekuensi rapat komite audit karena semakin sering diadakannya rapat dengan manajemen maka komite audit dapat lebih fokus pada identifikasi permasalahan maupun upaya manipulasi laba.

Motivasi ketiga adalah kualitas auditor dalam hubungannya denganstrategi pihak manajemen terhadap praktek manajemen laba di perbankan.Salah satu keunggulan KAP 
big four terletak pada keahlian dan pengalaman tim audit atas usaha auditee dan lingkungan industrinya yang tentunya memperkuat kompetensi auditor dalam melakukan audit dan memungkinkan auditor untuk dapat mendeteksi manajemen laba yang terjadi. Penggunaan kualitas auditor sebagai variabel moderasi pernah digunakan dalam penelitian oleh Tresnaningsih (2008). Menurut Tresnaningsih (2008) auditor yang tergabung dalam KAP big four dinilai memiliki kualitas yang tinggi yang dapat mengidentifikasi masalah keagenan yang timbul sehingga peran auditor sebagai organ eksternal GCG dapat memperlemah hubungan antara free cash flow yang tinggi yang disertai dengan kesempatan pertumbuhan rendah dengan akrual diskresioner yang meningkatkan laba. Berbeda dengan Tresnaningsih (2008), penelitian ini menggunakan kualitas auditor sebagai moderasi pada hubungan antara strategi yang dapat digunakan manajer (PPA kredit yang diberikan) serta indikator kinerja kredit (rasio kredit bermasalah) terhadap manajemen laba.

\section{LITERATURE REVIEW}

Konsep Corporate Governance (CG) merupakan salah satu mekanisme yang diharapkan dapat menekan terjadinya praktek manajemen laba. CG dapat mendukung terciptanya transparansi pengungkapan dan praktek akuntansi yang berkualitas tinggi (Ugbede et al., 2013). Tujuan diterapkannya CG adalah untuk menjaga kualitas pelaporan keuangan. Dewan komisaris sebagai fungsi pengawasan memiliki peran yang penting dalam praktek GCG, termasuk pengawasan terhadap manajemen puncak serta proses pelaporan keuangan sehingga dapat menghasilkan pelaporan keuangan yang berkualitas tinggi (Hari, 2012). Keberadaan dewan komisaris dapat menekan terjadinya praktek manajemen laba oleh manajemen.

Penelitian terdahulu oleh Hashim and Devi (2008) terdapat hubungan signifikan antara beberapa karakteristik dewan komisaris dengan manajemen laba, karakteristik tersebut meliputi: jumlah anggota dewan komisaris, adanya komisaris independen, frekuensi rapat dewan komisarisserta anggota dewan komite. Namun jumlah dewan komisaris yang besar cenderung tidak efektif dalam melakukan fungsi pengawasan.

Komite audit memiliki peran yang penting dalam rangka meningkatkan kinerja perusahaan terutama dari aspek pengendalian. Selain dewan komisaris, implementasi CG yang efektif tercermin dari adanya komite audit. Beberapa fungsi komite audit yaitu: membantu kelancaran tugas dewan komisaris seperti melakukan mengevaluasi terhadap kebenaran informasi yang disampaikan oleh direksi kepada komisaris, menilai efektivitas pengendalian internal sehingga dapat memberikan rekomendasi tentang peningkatan efektivitas internal auditor untuk meningkatkan sistem pengendalian internal perusahaan, melakukan sinergi dengan internal auditor misalnya melakukan audit 
gabunganuntuk aspek-aspek strategis yang memerlukan pendalaman audit lebih lanjut (Effendi, 2005).

Kredit yang disalurkan oleh bank tidaklah bebas risiko sehingga dalam pelaksanaannya bank harus tetap memperhatikan asas-asas perkreditan yang sehat. Untuk meminimalisasi risiko tersebut perlu adanya agunan yang cukup dan komitmen serta integritas dari pihak debitur dalam melunasi hutang sesuai dengan yang diperjanjikan. Penilaian terhadap asetproduktif didasarkan pada tingkat kolektibiltas kredit. Penggolongan kolektibilitas aset produktif tergantung pada pada kredit yang diberikan danindikator utamanya adalah ketepatan pembayaran pengembalian pokok dan bunga serta 5 kemampuan debitur baik ditinjau dari usaha maupun nilai agunan kredit yang bersangkutan (Prasetia, 2010). Berdasarkan Surat Keputusan Direksi Bank Indonesia (SKDIR BI) Nomor 31/147/Kep/DIR pasal 6 ayat 1 (Bank Indonesia, 1998), membagi tingkat kolektibilitas kredit menjadi lima yaitu: kredit lancar, kredit dalam perhatian khusus, kredit tidak lancar, kredit diragukan dan kredit macet.

Kantor akuntan publik (KAP) memiliki auditor eksternal yang berperan sebagai tenaga ahli dalam memberikan layanan kepada publik, salah satunya adalah audit laporan keuangan. Auditor eksternal berperan memberikan penilaian berupa opini secara obyektif dan independen ataskewajaran penyajian laporan keuangan yang disusun oleh manajemen suatu perusahaan. Dengan demikian, auditor eksternal dapat menjadi mekanisme kontrol dalam upaya manajemen menyajikan informasi keuangan yang handal, dapat dipercaya dan bebas dari praktek manipulasi. KAP big four memiliki beberapa keunggulan dibandingkan dengan nonbig four yaitu adanya peer review, spesialisasi pelatihan dan alokasi penugasan berdasarkan sektor industri, memiliki posisi lebih kuatdalam bernegosiasi terhadap klien yang berniat mengadospsi praktik akuntansi yang agresif.

PPA kredit yang diberikan dapat dimanfaatkan manajer sebagai alat manipulasi dalam praktek manajemen laba. Hal ini berhubungan dengan tingkat kredit bermasalah yang merupakan salah satu indikator kesehatan bankyang diinformasikan dalam laporan keuangan (Isa, Choong \& Fie, 2013). Manipulasi PPA kredit yang diberikan dan kredit bermasalah dapat mengarahkan investor maupun stakeholder pada pengambilan keputusan yang salah. Auditor eksternal merupakan profesional yang yang memiliki keahlian 6 dan kompetensi menilai kinerja manajemen dalam menyajikan informasi keuangan yang handal, dapat dipercaya dan bebas dari praktek manipulasi.

\section{RESEARCH METHODS}

Explain in detail about the research design, settings, time frame, variables, population, samples, sampling, instruments, data analysis, and information of ethical clearance fit test. The method of this paper is library method, library method is the 
method that emphasize the use of literature as the primary data source. This research is a quantitative study that applies the Johansen Integration Test and Vector Error Correction Model to see the long-term impact and shock response on certain variables...(Calibri, 12, Justify)

Metode analisis data yang akan dipergunakan dalam penelitian ini adalah analisis regresi moderasi. Menurut Ghozali (2011), pendekatan regresi tersebut sesuai karenadapat mempertahankan intergritas sampel dan memberikan dasar untuk mengontrol pengaruh variabel moderator. Berikut adalah model persamaan regresi moderasi untuk menguji hipotesis penelitian ini adalah:

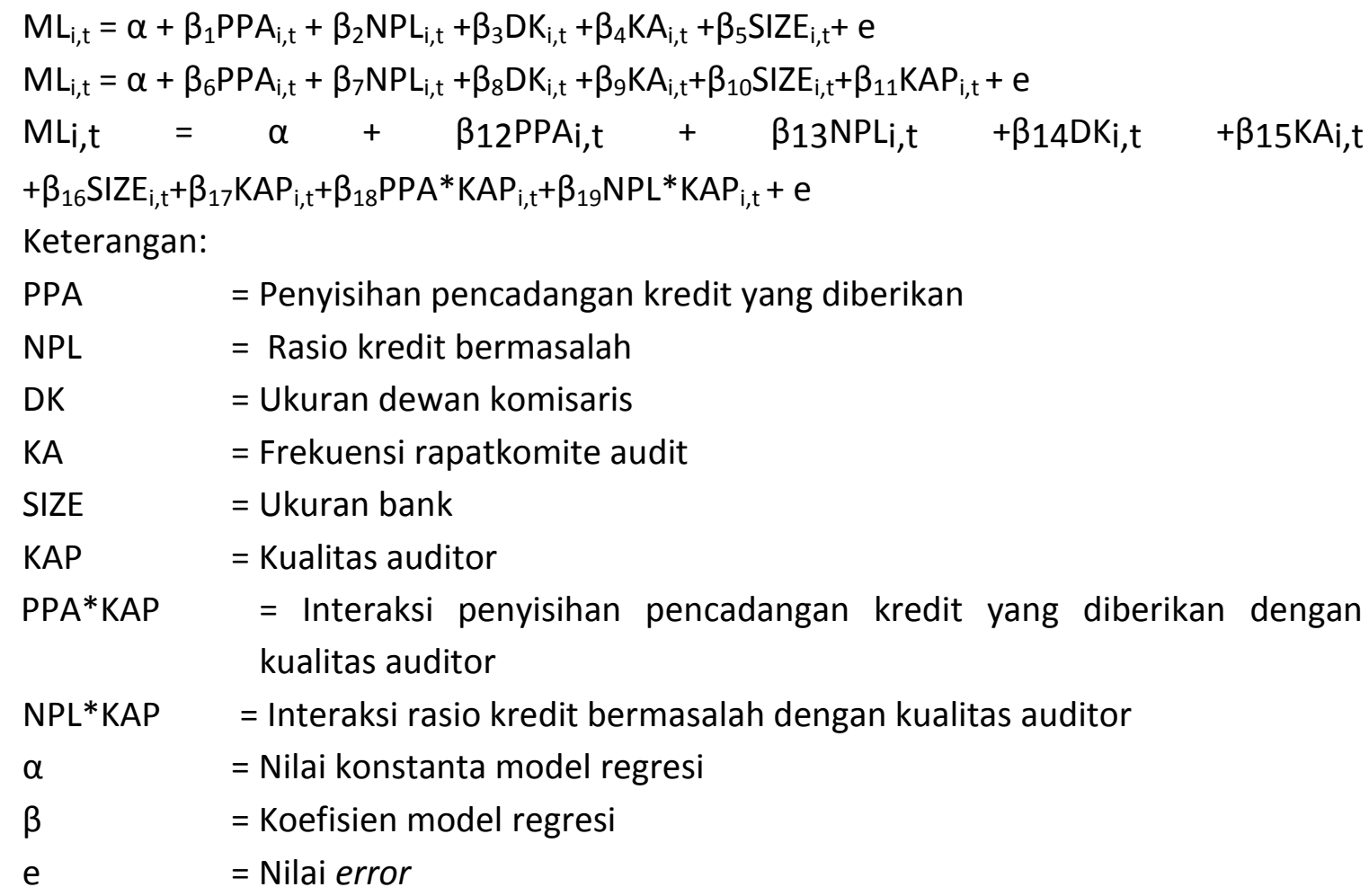

\section{RESULT AND ANALYSIS}

\section{Pengaruh PPA Kredit Yang Diberikan Terhadap Manajemen Laba}

PPA kredit yang diberikan tidak berpengaruh terhadap manajemen laba. Hasil tersebut berbeda dengan penelitian oleh Abaoub et al. (2013) maupun Tsitinidis and Duru (2013) yang menyimpulkan bahwa penyisihan tersebut memiliki pengaruh yang signifikan terhadap manajemen laba. Dengan demikian, dapat dikatakan bahwa hipotesis H1 terkait pengaruh PPA kredit yang diberikan terhadap manajemen laba tidak dapat didukung. PPA kredit yang diberikan merupakan suatu akrual yang besar bagi bank sehingga manajer dapat memaksimalkan kemakmurannya dengan memanfaatkan penyisihan pencadangan kredit yang diberikan untuk mengatur tingkat perolehan laba 
sesuai dengan motivasi manajer, baik berupa pemerataan, peningkatan ataupun penurunan laba (Tsitinidis \& Duru, 2013). Namun dalam penelitian ini disimpulkan bahwa PPA kredit yang diberikan tidak berpengaruh terhadap manajemen laba dalam perbankan, hal ini disebabkan karena perbankan merupakan industri yang diatur secara ketat sehingga mengurangi motivasi manajemen dalam melakukan manipulasi laba. Selain itu manajer telah menyadari bahwa meskipun besar kesempatan memanipulasi laba melalui penyisihan pencadangan kredit yang diberikan, mengingat proporsi aset berupa kredit yang diberikan dalam perbankan di Indonesia yaitu berkisar antara $37 \%$ sampai dengan 93\% dari total aset, namun berhubung tingkat laba yang dicapai sudah cukup tinggi atau sudah sesuai dengan utilitasnya maka penyisihan pencadangan justru akan berdampak pada pengurangan utilitas 13 manajer. Disamping itu, manajer menilai bahwa metode manajemen laba akrual lebih beresiko karena lebih mudah terdeteksi sehingga kemungkinan manajer lebih memilih metode manajemen laba riil. Kesimpulan tersebut berbeda dengan hasil penelitian oleh Abaoub et al. (2013) karena tingginya fluktuasi pencapaian laba perbankan di Tunisia, sehingga manajer termotivasi untuk melakukan manipulasi laba melalui penyisihan pencadangan untuk mencapai tingkat laba yang sesuai utilitasnya. Penguasaan informasi sehubungan dengan penyisihan pencadangan kredit yang diberikan sebagai alat manajer untuk memaksimalkan utilitasnya, tidak mampu mendukung praktek manajemen laba. Hal tersebut bertentangan dengan teori keagenan yang menyatakan bahwa pihak yang memiliki, menguasai informasi yang lebih lengkap cenderung melakukan manipulasi laba untuk memaksimalkan utilitasnya.

\section{Pengaruh Rasio Kredit Bermasalah Terhadap Manajemen Laba}

Rasio kredit bermasalah secara tidak berpengaruh terhadap manajemen laba perbankan. Hasil tersebut sesuai dengan kesimpulan penelitian oleh Chang et al. (2008) dan Dong et al. (2012) yang menyimpulkan bahwa rasio kredit bermasalah tidak berpengaruh terhadap manajemen laba. Dengan demikian, dapat dikatakan bahwa hipotesis $\mathrm{H} 2$ terkait pengaruh rasio kredit bermasalah terhadap manajemen laba tidak dapat didukung. Rasio kredit bermasalah tidak berpengaruh terhadap manajemen laba diduga karena peranan CG dalam perbankan telah berjalan dengan baik. Berdasarkan SE BI Nomor 15/15/DPNP tahun 2013 tentang Pelaksanaan Good Corporate Governance bagi Bank Umum (Bank Indonesia, 2013), pelaksanaan GCG perbankan harus berlandaskan pada beberapa prinsip dasar salah satunya adalah pertangungjawaban. 14 Berdasarkan prinsip tersebut, bank wajib dikelola sesuai dengan peraturan perundangundangan yang berlaku dan sesuai dengan prinsip yang sehat. Sedangkan berdasarkan PBI Nomor 8/4/PBI/2006 tentang Pelaksanaan Good Corporate Governance bagi Bank Umum (Bank Indonesia, 2006) mengatur sanksi bagi perbankan yang tidak melaksanakan GCG sesuai peraturan Bank Indonesia, sehingga besar kemungkinan 
manajemen lebih memilih untuk patuh daripada menanggung resiko akibat praktek manajemen laba melalui pengaturan tingkat rasio kredit bermasalah. Tingkat kredit bermasalah sebagai alat manajer untuk memaksimalkan utilitas dengan menyajikan informasi yang bias, tidak mampu mendukung praktek manajemen laba. Hal tersebut sesuai dengan teori stakeholder dimana pemahaman akan lingkungan stakeholder akan membuat manajer berupaya menghasilkan kinerja pengelolaan kredit yang efektif sehingga meningkatkan kepercayaan dari narrow sense stakeholder.

\section{Pengaruh Ukuran Dewan Komisaris Terhadap Manajemen Laba}

Ukuran dewan komisaris tidak berpengaruh terhadap manajemen laba. Hasil tersebut sesuai dengan kesimpulan penelitian oleh Hari (2012) yang menyimpulkan bahwa ukuran dewan komisaris tidak berpengaruh terhadap manajemen laba. Dengan demikian, dapat dikatakan bahwa hipotesis H3 terkait ukuran dewan komisaris terhadap manajemen laba tidak dapat didukung. Dewan komisaris sebagai fungsi organ pengawasan memiliki peran yang penting dalam praktek GCG, termasuk pengawasan terhadap manajemen puncak serta proses pelaporan keuangan sehingga dapat menghasilkan pelaporan keuangan yang berkualitas tinggi, namun dari hasil penelitian tersebut disimpulkan bahwa ukuran dewan komisaris tidak berpengaruh 15 terhadap praktek manajemen laba perbankan. Beberapa penyebabnya antara lain: ukuran dewan komisaris yang umumnya berjumlah dua sampai sembilan orang tidak mampu mengidentifikasi metode praktek manajemen laba yang dilakukan oleh manajemen sehingga kinerja pihak manajemen dinilai sudah sesuai dengan aturan-aturan yang berlaku; dewan komisaris tidak memiliki cukup waktu untuk memantau dan menganalisa kebijakankebijakan operasional yang sebenarnya bertujuan memaksimalkan utilitas manajer; dewan komisaris menilai kinerja manajemen yang tercermin dari perolehan laba sudah memenuhi ekspektasi stockholder maupun stakeholder.

\section{Pengaruh Frekuensi Rapat Komite Audit Terhadap Manajemen Laba}

Frekuensi rapat komite audit tidak berpengaruh terhadap manajemen laba. Hasil tersebut sesuai dengan kesimpulan penelitian oleh Pamudji and Trihartati (2010) dan Baccouche et al. (2013) yang berpendapat bahwa frekuensi rapat komite audit tidak dapat menekan praktek manajemen laba yang dilakukan oleh manajemen, namun berbeda dengan penelitian oleh Ugbede et al. (2013) yang berpendapat bahwa frekuensi rapat yang lebih sering dapat membantu komite audit dalam memfokuskan diri pada identifikasi potensi adanya motivasi manipulasi oleh manajer bank. Dengan demikian, dapat dikatakan bahwa hipotesis H4 terkait frekuensi rapat komite audit terhadap manajemen laba tidak dapat didukung. Namun hasil penelitian tersebut menunjukkan tidak adanya pengaruh antara frekuensi rapat komite audit dengan tingkat manajemen laba. Adapun penjelasan yang dapat digunakan untuk menerangkan hal tersebut adalah: 
rapat yang diselenggarakan komite audit hanya bersifat formalitas untuk memenuhi persyaratan yang wajib; rapat hanya membahas informasi keuangan yang 16 dihasilkan oleh manajemen berupa laporan keuangan, laporan proyeksi dan laporan lain yang pada umumnya telah dipersiapkan dengan rapi dan disertai dengan catatancatatan yang berfokus pada hal-hal yang secara umum dibahas setiap rapat komite audit; rapat jarang dihadiri baik oleh pihak manajemen maupun oleh auditor ekstemal, sehingga permasalahan dalam penyusunan laporan keuangan tidak dapat diidentifikasi oleh komite audit.

\section{Pengaruh Ukuran Bank Terhadap Manajemen Laba}

Ukuran bank berpengaruh signifikan terhadap manajemen laba. Hasil tersebut sesuai dengan kesimpulan penelitian oleh Akindayomi (2012), dimana bank dengan ukuran yang besar cenderung melakukan manajemen laba melalui pemerataan laba. Dalam rangka memelihara kelangsungan usahanya, bank wajib menjaga kualitas aset. Sesuai dengan PBI Nomor 14 Tahun 2012 (Bank Indonesia, 2012b), pihak manajemen wajib menilai, memantau serta mengambil langkah-langkah yang diperlukan agar kualitas aset senantiasa baik. Sedangkan berdasarkan Undang Undang Nomor 10 Tahun 1998 Tentang Perbankan (Bank Indonesia, 1998) disebutkan bahwa bank wajib memelihara kesehatan bank, kualitas aset serta kegiatan usahanya sesuai dengan prinsip kehati-hatian. Peraturan dan Undang-undang tersebut menjadi pedoman bagi manajemen bank dalam pengelolaan aset yang dimiliki. Penelitian ini menyimpulkan bahwa ukuran berpengaruh signifikan terhadap manajemen laba, hal ini disebabkan karena ketatnya peraturan perundang-undangan perbankan sehubungan dengan pengelolaan aset tidak dapat menghambat motivasi manajer dalam upaya melakukan manajemen laba melalui pemerataan laba.

Sedangkan dalam peneliti terdahulu karena pada periode penelitian oleh Akindayomi (2012), perbankan di Nigeria berada dalam kondisi distressed 17 (sukar) sehingga dalam upaya untuk tetap dapat menginformasikan kinerja perolehan laba yang baik kepada publik maupun stakeholder, manajer cenderung memanfaatkan pengaturan penyisihan pencadangan yang berasal dari aset yang dimiliki oleh bank. Teori biaya politik dalam teori akuntansi positif yang diproksikan dengan ukuran ternyata mampu mendukung praktek manajemen laba, hal tersebut sesuai dengan hipotesis teori tersebut dimana makin besar ukuran suatu entitas maka makin besar insentif untuk melakukan manipulasi laba. Hal ini karena bank merupakan suatu entitas yang secara politik ter-expose pada publik sehingga manajemen berupaya untuk menyajikan kinerja yang lebih baik.

\section{Pengaruh Kualitas Auditor Terhadap Manajemen Laba}

Kualitas auditor tidak berpengaruh terhadap manajemen laba. Hasil tersebut sesuai dengan kesimpulan penelitian oleh Christiantie and Christiawan (2013), 
Handayani and Rachadi (2009) dan Ugbede et al. (2013). Tujuan audit laporan keuangan sesuai Pernyataan Standar Auditing (PSA) Nomor 02 adalah untuk menyatakan pendapat tentang kewajaran, dalam semua hal yang material, posisi keuangan, hasil usaha, perubahan ekuitas dan arus kas sesuai dengan prinsip akuntansi yang berlaku umum di Indonesia (Ikatan Akuntan Indonesia, 2001). Pada tahap perencanaan audit, berdasarkan PSA Nomor 22 auditor wajib melakukan prosedur analitik salah satunya melalui perbandingan laba kotor untuk meningkatkan pemahaman auditor atas bisnis klien serta untuk mengidentifikasikan adanya transaksi maupun peristiwa yang tidak biasa dan jumlah, rasio serta trend yang dapat menunjukkan masalah yang berhubungan dengan laporan keuangan (Ikatan Akuntan Indonesia, 2001). Berdasarkan PSA Nomor 26, pengetahuan 18 dan pertimbangan profesional auditor berperan penting pada tahap desain serta penentuan ukuran sampling audit untuk memperoleh kecukupan bukti audit (Ikatan Akuntan Indonesia, 2001).

Dalam upaya mencapai mutu kinerja atau kualitas audit yang tinggi, auditor wajib memenuhi standar-standar tersebut. Namun hal tersebut tidak dapat mencerminkan kualitas auditor dalam upaya mengurangi praktek manajemen laba karena: prosedur untuk penugasan general audit yang dilakukan KAP adalah untuk menyatakan opini atas kewajaran laporan keuangan yang disusun manajemen, bukan secara khusus untuk mendeteksi praktek manajemen laba; trend laba kotor yang tidak menunjukkan suatu pergerakan fluktuatif sehingga tidak menimbulkan pertanyaan lebih lanjut dari pihak auditor; manajemen berhasil meyakinkan auditor bahwa aktivitas pengendalian dapat diandalkan sehingga auditor tidak banyak melakukan pengujian secara mendetail; pengujian dalam penugasan audit adalah secara sampling sehingga terdapat kemungkinan adanya transaksi atau perlakuan akuntansi bersifat manipulatif yang tidak termasuk dalam sample pengujian.

\section{Pengaruh Moderasi Kualitas Auditor Dalam Hubungan PPA Kredit Yang Diberikan Terhadap Manajemen Laba}

Kualitas auditor sebagai variabel moderasi tidak dapat memperlemah hubungan antara PPA kredit yang diberikan terhadap manajemen laba. Kualitas auditor seharusnya dapat memperlemah motivasi manajer dalam memanfaatkan penyisihan pencadangan kredit yang diberikan untuk memanipulasi laba. Pelatihan, pengalaman dan pemahaman auditor mengenai industri perbankan maupun peraturan perundangundangan yang terkait dapat menjadi dasar dalam mengenali tindakan klien yang merupakan unsur tindakan pelanggaran hukum. Pemerintah melalui Bank Indonesia 19 mengatur penyisihan pencadangan aset perbankan dalam PBI Nomor 14/15/PBI/2012 Pasal 1 (Bank Indonesia, 2012b). Berdasarkan PSA Nomor 31, penugasan audit umum laporan keuangan yang dilaksanakan berdasarkan standar auditingtidak meliputi prosedur audit 
yang dirancang secara khusus untuk mendeteksi unsur tindakan pelanggaran hukum. Namun, prosedur audit yang ditujukan untuk memberikan pendapat atas laporan keuangan memungkinkan pengarahan perhatian auditor tentang kemungkinan adanya unsur tindakan pelanggaran hukum. Dalam PSA Nomor 31, terdapat dua kondisi terkait kemungkinan adanya unsur tindakan pelanggaran hukum yaitu: adanya informasi spesifik atau tidak adanya informasi spesifik tentang adanya kemungkinan unsur tindakan pelanggaran hukum. Jika tidak ada informasi spesifik dan auditor yakin akan pernyataan tertulis manajemen terkait tidak adanya unsur pelanggaran hukum yang berdampak pada pengungkapan laporan keuangan, maka tidak perlu dilakukan prosedur audit lebih lanjut.

Dalam penelitian ini moderasi kualitas auditor tidak dapat memperlemah hubungan antara PPA kredit yang diberikan dengan manajemen laba. Hal ini dapat disebabkan karena ketatnya peraturan sesuai PBI Nomor 14/15/PBI/2012 dan PBI Nomor 14/14/PBI/2012 (Bank Indonesia, 2012a), dimana Bank Indonesia juga mengawasi melalui laporan keuangan publikasi bulanan, triwulanan yang termasuk didalamnya wajib untuk menginformasikan penyisihan pencadangan aset. Dengan demikian, mengurangi kesempatan manajer untuk melakukan pengaturan atau memanipulasinya. Selain itu, keahlian dan pengalaman auditor belum dapat mengidentifikasi metode praktek manipulasi laba melalui penyisihan pencadangan yang dijalankan oleh manajemen.

\section{Pengaruh Moderasi Kualitas Auditor Dalam Hubungan Rasio Kredit Bermasalah Terhadap Manajemen Laba}

Kualitas auditor sebagai variabel moderasi tidak dapat memperlemah hubungan antara rasio kredit bermasalah terhadap manajemen laba. Kredit bermasalah terjadi karena terdapat kredit dengan kategori kolektibilitas 3, 4 dan 5. Bank Indonesia menetapkan batas maksimum rasio kredit bermasalah adalah sebesar $5 \%$. Hal ini menjadi resiko bagi bank ketika jumlah kredit bermasalah meningkat karena akan diikuti dengan peningkatan beban penyisihan pencadangan atau dengan kata lain akan mengurangi perolehan laba. Kualitas auditor sebagai variabel moderasi tidak dapat memperlemah hubungan antara rasio kredit bermasalah terhadap manajemen laba karena rata-rata rasio kredit bermasalah bank berada dibawah batas yang ditentukan Bank Indonesia. Selain itu, manajemen telah menjalankan sisdur analisa calon debitur, penyaluran, pemantauan serta penagihan kredit sesuai pedoman yang berlaku.

\section{CONCLUSION}

Model pengukuran manajemen laba Adjusted Jones yang dikembangkan oleh Yasuda et al. (2004) dapat digunakan untuk mendeteksi praktek manajemen laba dalam industri perbankan, karena perbedaan karakteristik industri perbankan dengan industri 
lainnya menyebabkan pengukuran untuk identifikasi manajemen laba juga perlu disesuaikan. Berdasarkan hasil penelitian sehubungan dengan ukuran dewan komisaris yang tidak berpengaruh terhadap praktek manajemen laba, diidentifikasi bahwa jumlah rata-rata dewan komisaris bank dalam sampel penelitian ini umumnya adalah sebanyak lima orang meski ukuran bank berbeda-beda.

Bagi penyusun kebijakan Kebijakan pengungkapan sehubungan dengan dasar kriteria pemberian bonus manajemen dan sifat transaksi, persyaratan maupun pembatasan dari pihak kreditur terkait pinjaman yang diterima bank akan dapat melengkapi penelitian yang berlandaskan pada teori akuntansi positif dalam perbankan. Bagi penelitian selanjutnya Penelitian selanjutnya diharapkan dapat menambah periode penelitian jangka panjang, dengan demikian akan melengkapi kontribusi penelitian terkait pengaruh PPA kredit yang diberikan, rasio kredit bermasalah, ukuran dewan komisaris, frekuensi rapat komite audit, ukuran bank dan kualitas auditor eksternal terhadap manajemen laba. Penelitian selanjutnya diharapkan dapat meneliti pengaruh moderasi dari kualitas auditor dengan proksi yang berbeda (misalkan: spesialisasi industri KAP) dalam mempengaruhi hubungan antara strategi manajemen laba, karakteristik organ pengawas dalam GCG terhadap praktek manajemen laba.

\section{REFERENCES}

Abaoub, E., Homrani, K. \& Ben Gamra, S. (2013). The Determinants of Earnings Management: Empirical Evidence in the Tunisian Banking Industry (1999-2010). Journal of Business Studies Quarterly, 4(3).

Akindayomi, A. (2012). Earnings Management And The Banking Crisis Of The 1990s: Evidence From Nigeria. Academy of Accounting \& Financial Studies Journal, 16(3).

Baccouche, S., Hadriche, M. \& Omri, A. (2013). The Impact Of Audit Committee Multiple-Directorships On Earnings Management: Evidence From France. Journal of Applied Business Research (JABR), 29(5), 1333-1342.

Surat Keputusan Direksi Bank Indonesia Nomor 31/147/Kep/DIR tentang Kualitas Aktiva Produktif (1998).

Peraturan Bank Indonesia Nomor 8/4/PBI/2006 tentang Pelaksanaan Good Corporate Governance bagi Bank Umum (2006).

Peraturan Bank Indonesia Nomor 14/14/PBI/2012 tentang Transparansi dan Publikasi Laporan Bank (2012a).

Peraturan Bank Indonesia Nomor 14/15/PBI/2012 tentang Penilaian Kualitas Aset Bank Umum (2012b).

Surat Edaran Bank Indonesia No. 15/15/DPNP tentang Pelaksanaan Good Corporate Governance bagi Bank Umum (2013). 
Chang, R. D., Shen, W. H. \& Fang, C. J. (2008). Discretionary Loan Loss Provisions And Earnings Management for the Banking Industry. International Business \& Economics Research Journal (IBER), 7(3).

Christiantie, J. \& Christiawan, Y. J. (2013). Analisis Pengaruh Mekanisme Corporate Governance dan Reputasi KAP terhadap Aktivitas Manajemen Laba. Business Accounting Review, 1(2), 275-285.

Cohen, D. A., Dey, A. \& Lys, T. Z. (2008).

Real and Accrual-Based Earnings Management in the Pre-and Post- SarbanesOxley Periods. The Accounting Review, 83(3), 757-787.

Dong, X., Liu, J. \& Hu, B. (2012). Research on the Relationship of Commercial Bank's Loan Loss Provision and Earning Management and Capital Management*. Journal of Service Science and Management, 5(2), 171-

179.

Effendi, M. A. (2005). Peranan Komite Audit dalam Meningkatkan Kinerja Perusahaan. Jurnal Akuntansi Pemerintah, 1(1).

Ghozali, I. 2011. Aplikasi Analisis Multivariate dengan Program IBM SPSS19. Semarang: Badan Penerbit Universitas Diponogoro.

Guna, W. I. \& Herawaty, A. (2010). Pengaruh Mekanisme Good Corporate Governance, Independensi Auditor, Kualitas Audit dan Faktor Lainnya terhadap Manajemen Laba. Jurnal Bisnis dan Akuntansi, 12(1), 53-68.

Handayani, R. S. \& Rachadi, A. D. (2009). Pengaruh Ukuran Perusahaan terhadap Manajemen Laba. Jurnal Bisnis dan Akuntansi, 11(1), 33-56.

Hari, B. (2012). Karakteristik Dewan Komisaris dan Manajemen Laba di Indonesia. Majalah Ekonomi, 22(1).

Hashim, H. A. \& Devi, S. S. (2008). Board Independence, CEO Duality and Accrual Management: Malaysian Evidence. Asian Journal of Business and Accounting, 1(1).

Healy, P. M. \& Wahlen, J. M. (1999). A review of the earnings management literature and its implications for standard setting. Accounting Horizons, 13(4), 365-383.

Iannotta, G. \& Kwan, S. 2013. Effects of Earnings Management and Delays In Loss Recognition on Bank Opacity.

Standar Profesional Akuntan Publik (2001). Isa, M. Y. M., Choong, Y. V. \& Fie, D. Y. G. (2013). Loan Loss Provisioning Practices. Journal of Modern Accounting and Auditing, 9(6), 814- 822.

Kamau, A. W. (2011). Intermediation Efficiency and Productivity of the Banking Sector in Kenya. Interdisciplinary Journal of Research in Business, 1(9), 2-26.

Neffati, A., Fredj, I. B. \& Schalck, C. (2011). Earnings Management and Banking Performance: A Stochastic- Frontier Analysis on US Bank Mergers. Interdisciplinary Journal of Research in Business, 1(6), 58-65. 
Pamudji, S. \& Trihartati, A. (2010). Pengaruh Independensi dan Efektivitas Komite Audit Terhadap Manajemen Laba. Jurnal Dinamika Akuntansi, 2(1).

Prasetia, H. (2010). Analisis Pengaruh Kualitas Aktiva Produktif Terhadap Tingkat Kesehatan Bank Pada Bank Perkreditan Rakyat di Sumatera Utara.

Roychowdhury, S. (2006). Earnings Management Through Real Activities Manipulation. Journal of accounting and economics, 42(3), 335-370.

Scott, W. R. 2012. Financial Accounting Theory (Vol. 6): Prentice Hall Upper Saddle River, NJ.

Siswantaya, I. G. (2007). Mekanisme Corporate Governance dan Manajemen Laba Studi Pada Perusahaan-Perusahaan yang Terdaftar di Bursa Efek Jakarta. Program Pascasarjana Universitas Diponegoro.

Subramanyam, K. \& Wild, J. (2009). Financial Statement Analysis. McGraw-Hill, New York, NY.

Tresnaningsih, E. (2008). Manajemen Laba Pada Perusahaan Dengan Permasalahan Free Cash Flow dan Peran Moderasi dari Monitoring Eksternal. Jurnal Akuntansi dan Keuangan Indonesia, 5(1), 30-49.

Tsitinidis, A. \& Duru, K. (2013). Managerial Incentives and Earnings Management: An Empirical Examination of the Income Smoothing in the Nordic Banking Industry.

Ugbede, O., Lizam, M. \& Kaseri, A. (2013). Corporate Governance and Earnings Management: Empirical Evidence from Malaysian and Nigerian Banks.

Yasuda, Y., Okuda, S. \& Konishi, M. (2004). The Relationship Between Bank Risk and Earnings Management: Evidence from Japan. Review of Quantitative Finance and Accounting, 22(3), 233-248. 